NBER WORKING PAPER SERIES

\title{
FINANCIAL EDUCATION AND ACCESS TO SAVINGS ACCOUNTS: COMPLEMENTS OR SUBSTITUTES? EVIDENCE FROM UGANDAN YOUTH CLUBS
}

\author{
Julian C. Jamison \\ Dean Karlan \\ Jonathan Zinman \\ Working Paper 20135 \\ http://www.nber.org/papers/w20135
}

\author{
NATIONAL BUREAU OF ECONOMIC RESEARCH \\ 1050 Massachusetts Avenue \\ Cambridge, MA 02138
}

May 2014

This paper is the result of independent research and does not necessarily represent the views of the Consumer Financial Protection Bureau, the United States Government, or the National Bureau of Economic Research. We thank the Financial Education Fund from DFID for funding. Institutional Review Board approval for human subjects protocols from Innovations for Poverty Action(\#113.10February-006 and Yale University \#1002006384. From Innovations for Poverty Action, we thank Sarah Kabay, Daniel Katz, Sana Khan, Charity Komujurizi, Matthew Lowes, Justin Loiseau, Joseph Ndumia, Doug Parkerson, Pia Raffler, Elana Safran, Marla Spivack, and Glynis Startz for research support throughout the project and analysis. We thank the Freedom from Hunger and Straight Talk team for collaboration on development of the financial education curriculum, FINCA for the provision of the bank accounts, and four dioceses of the Church of Uganda for their cooperation throughout.

NBER working papers are circulated for discussion and comment purposes. They have not been peerreviewed or been subject to the review by the NBER Board of Directors that accompanies official NBER publications.

(C) 2014 by Julian C. Jamison, Dean Karlan, and Jonathan Zinman. All rights reserved. Short sections of text, not to exceed two paragraphs, may be quoted without explicit permission provided that full credit, including $\odot$ notice, is given to the source. 
Financial Education and Access to Savings Accounts: Complements or Substitutes? Evidence from Ugandan Youth Clubs

Julian C. Jamison, Dean Karlan, and Jonathan Zinman

NBER Working Paper No. 20135

May 2014

JEL No. D12,D91,O12

\begin{abstract}
Evidence on the effectiveness of financial education and formal savings account access is lacking, particularly for youth. We randomly assign 250 youth clubs to receive either financial education, access to a cheap group account, or both. The financial education treatments increase financial literacy; the account-only treatment does not. Administrative data shows the education plus account treatment increases bank savings relative to account-only. But survey-measured total savings shows roughly equal increases across all treatment arms. Earned income also increases in all treatment arms. We find little evidence that education and account access are strong complements, and some evidence they are substitutes.
\end{abstract}

Julian C. Jamison

Senior Economist

Office of Research

Consumer Financial Protection Bureau

1700 G Street NW

Washington, DC 20552

julison@gmail.com

Dean Karlan

Department of Economics

Yale University

P.O. Box 208269

New Haven, CT 06520-8629

and NBER

dean.karlan@yale.edu
Jonathan Zinman

Department of Economics

Dartmouth College

314 Rockefeller Hall

Hanover, NH 03755

and NBER

jzinman@dartmouth.edu

An online appendix is available at:

http://www.nber.org/data-appendix/w20133 
Interventions to facilitate saving are touted worldwide as anti-poverty tools. These interventions are motivated by evidence suggesting that the poor have substantial, potentially latent, demand for accumulating financial assets (Karlan, Ratan, and Zinman 2013). Surveys indicate poor households do tend to have some surplus that they use for non-essential expenditures (Banerjee and Duflo, 2007). Similarly, detailed "diary" studies document complexity in poor households' financial portfolios and highlight the demand for small irregular flows to be aggregated into lump sums for household or business investment (Rutherford, 2000; Collins et al., 2009). When formal savings products are unavailable or unaffordable, the poor often save under mattresses, in informal groups, and/or in livestock.

One increasingly prevalent pro-saving intervention is to increase access to basic formal saving accounts. This approach is motivated by an apparent lack of access, particularly for the world's poor: only $22 \%$ of adults worldwide report having saved at a formal financial institution in the past 12 months, and only $23 \%$ of adults living on less than $\$ 2$ a day report having an account at a formal financial institution (Demirguc-Kunt and Klapper 2012). Many microfinance institutions (MFIs) are responding by broadening their initial focus on microcredit to include the provision of savings products. MFIs have 72 million microsavings clients to date, compared to 94 million microcredit clients (www.mixmarket.org).

Recent evidence supports the hypothesis that efforts to expand access to basic accounts can have large, positive effects on household saving, income, and wellbeing. Burgess and Pande (2005) uses a natural experiment on bank expansion (i.e., both credit and savings) in India from 1977 to 1990 and finds a 2.22 percentage point reduction in rural poverty per one percentage point increase in the share of savings held by rural banks. More recently, several field experiments find large impacts of expanding access to formal accounts on savings rates (Ashraf, Karlan, and Yin 2006; Ashraf, Karlan, and Yin 2010; Dupas and 
Robinson 2013a; Dupas and Robinson 2013b; Brune et al. 2013; Prina 2013; Schaner 2013). Most of these studies also find impacts on downstream outcomes like income, expenditures, and decision power, and the magnitudes hint at more transformative impacts than found thus far in similar evaluations of microcredit (Banerjee 2013).

Financial education is another prevalent pro-saving intervention. This approach is motivated by descriptive evidence that most people lack basic financial knowledge. In India for instance, $26 \%$ of respondents provided no correct answers to four questions on basic financial principles, and only $3 \%$ answered all four questions correctly (Cole, Sampson, and Zia, 2011). Applying the same instrument in other less-developed countries yields similarly low levels of basic financial literacy (Xu and Zia, 2012).

However, the evidence that financial education, or other interventions designed to increase financial literacy, increases saving is mixed at best. Two recent meta-analyses of dozens of studies make different inferences, with Fernandes et al (2013) concluding "different approaches to financial education are required if one expects to produce effects on behavior larger than the very small effects we found", and Miller et al (2013) concluding "financial literacy and capability interventions can have a positive impact in some areas (increasing savings....)". Hastings, Madrian and Skimmyhorn (2013) concludes "the current literature is inadequate to draw firm conclusions about if and under what conditions financial education either works or is cost-effective." Karlan, Ratan and Zinman (2013) focuses on the handful of completed field experiments in developing countries and find "mixed (at best) impacts of financial literacy programs on literacy and downstream behaviors, and truly scant evidence on whether such interventions change... savings decisions."

We bring together the literatures on savings account access and financial education by randomly assigning each treatment, independently, across 240 
Ugandan youth groups, containing a total sample of 2680 individuals. A baseline survey shows that financial knowledge and bank account use are low in our setting (Section I-A). 60 groups were offered financial education in the form of a 10-week, 15-hour curriculum, designed by NGOs with local and international expertise, that focused on the formal financial system, savings practices, savings costs and benefits (relative to borrowing), and other aspects of personal financial management. 60 groups were offered easy access to a basic savings account with FINCA, a local and international microfinance institution with a banking charter in Uganda. To eliminate fees and minimize time costs, accounts were offered at the group level (one account per group), with groups responsible for maintaining a ledger with individual members' savings, and selected group members serving as bank field agents for handling deposits and withdrawals. 60 groups were offered both education and the group account, and 60 groups were offered neither (the control group).

Financial education and account participation rates are sufficient to identify treatment effects on saving and downstream outcomes. The financial education participation rate is about $50 \%{ }^{1}$ The savings account take-up rate is about $66 \%{ }^{2}$ We measure savings in FINCA using administrative data on the two study arms offered FINCA group accounts. We measure total/net savings, for all four study arms, using a follow-up survey conducted about 9 months after random assignment. The follow-up survey also allows us to estimate treatment effects on decision inputs (e.g., knowledge, literacy, numeracy, preferences) and downstream outcomes (income, activities, and expenditures).

\footnotetext{
${ }^{1}$ Financial education participation is measured as the mean or median attendance rate among group members in the education study arms. This is unusually high for financial education, and may be due in part to the distribution channel, which piggybacked on regular group meetings (Section I-C).

${ }^{2}$ Savings account take-up is measured as the proportion of groups in the two account-offer study arms that opened an account.
} 
Our study makes several contributions. First, the $2 \times 2$ design generates evidence on whether account access and financial education are complements or substitutes. The interventions might complement each other if education changes behavior only when there is an easy "on-ramp" to that behavior in the form of an account, or if account access changes behavior only when prospective savers have the knowledge required to navigate the formal financial system and/or use the account productively. Conversely, accounts may substitute for education if knowledge is not a prerequisite for saving, or if there is learning-by-doing. Second, we address concerns that self-reported data leads to upward-biased estimates of treatment effects by using bank data to complement survey data on savings. Because financial education for youth is typically implemented via schools, it is often difficult to use administrative bank data to measure impacts. Third, there have been relatively few field experiments with younger samples. ${ }^{3}$ Savings interventions may have different effects on youth than on adults due to differences in cognition (e.g., youth may be more teachable) and/or choice sets (e.g., youth may have fewer productive uses for savings and/or more life-cycle reasons to borrow). Fourth, and closely related, we have rich data on decision inputs that allows us to estimate effects on various aspects of financial literacy (broadly defined as finance-specific human capital), numeracy, preferences (risk, time, and social), and risk perceptions.

Our treatment effect estimates on decision inputs suggest that financial education has an impact but that account-ownership alone does not. The results suggest that, relative to the control group, financial education increases financial literacy, as measured by quiz questions in the follow-up survey. Some of this may be due to "teaching-to-the-test" (although even that would be encouraging

\footnotetext{
${ }^{3}$ Bruhn et al (2013) is the only completed study we know of using a field experiment with youth in a developing country setting; they find that adding a substantial financial education curriculum component to high schools leads to large increases in knowledge and self-reported savings.
} 
evidence), but not all elements of the curriculum show similar increases, as one would have expected if this were the primary driver of the results. There is also some evidence that financial education increases decision power and decreases risk tolerance and altruism.

Several sets of results suggest that financial education increases savings (defined as financial assets) and wealth. First, we use bank data on groups in the two study arms offered accounts. This administrative data, pulled about nine months post-treatment assignment, is free of any self-reporting biases but of course only captures saving at the partner bank, not total or net saving. These results suggest that there is a large marginal effect of financial education above and beyond account access, with savings $60-180 \%$ higher in the account+education group.

Turning to comparisons that the bank data cannot address, the survey data suggest that both the education-only and account+education arms increase total savings relative to the control group, by $5-50 \%$ depending on how we measure savings. The results are actually stronger for the education-only arm than the account+education arm (although this difference is only statistically significant for one out of six measures of savings), and hence do not support the hypothesis that account access and financial education are complements. Nor do the education arms produce significantly greater total savings than the account-only arm. We do not find evidence of significant treatment effects on borrowing or spending, or reductions in other assets, suggesting that the increases in financial assets translate into increases in wealth.

Does the increase in savings translate into substantial downstream impacts, as has been found in other studies? We start by examining effects on earned income, since even though our study participants are considered "youth" by Ugandan standards, they are also of working age (mean age of 24.5; SD of 3.5). We find that all three treatment arms increase earned income relative to the control group, 
with increases of $13-29 \%$ depending on the measure. We do not find evidence of significant treatment effects on days worked, occupation, or school attendance.

All told, the results suggest that the interventions produced a powerful feedback loop between saving and income, with little evidence of strong complementarity between account access and financial education with respect to total savings or downstream impacts, and some evidence of substitutability. In particular, we see statistically equivalent increases in both total saving and earned income between the account-only and education treatments. But our results cannot sharply distinguish between the two likely mechanisms driving the feedback loop: initial saving being used to fund productive investments, and/or motivation to save leading to increased work effort.

\section{Research Design and Implementation}

This section details our setting and methods, moving chronologically from sampling, to baseline survey, to treatment design, implementation, and take-up rates, to endline data collection, and finally to our empirical model for estimating treatment effects. Appendix Figure 1 shows the timeline of study activities. For each of the surveys the research team trained, hired, and monitored its own surveyors.

\section{a. Baseline Survey and Sample Characteristics}

The Church of Uganda provided access to its country-wide network of youth clubs. The average club has about 40 members (with a standard deviation that is also around 40 in our data), and engages in activities including bible study, choir, community service, continuing education, and travel to conventions with other clubs.

The research team selected 240 youth clubs from the vicinity of district capitals in each of Uganda's four regions (Appendix Figure 2). Clubs were eligible for the study if they met at least twice a month, had at least 12 members, 
and were located within a 60 minute-walk of public transportation. We measured eligibility characteristics using a club-level filter-survey, conducted in our targeted districts, in April and May of 2010. Amongst the eligible clubs, we then randomly chose 60 clubs per region for inclusion in the study sample frame.

After establishing the sample frame of 240 clubs, we conducted a detailed baseline survey of individual youth club members in May and June of 2010. We worked with the Church and club leaders to identify active members, and randomly selected 12 active members to survey. Surveys took place at each club's meeting place. Survey participants could earn money from preference elicitation tasks, with minimum earnings of 500 UGX and typical earnings of 1000-2000 UGX (US\$1 = 2,500UGX). We completed 2810 baseline surveys.

Table 1 (Columns 1-4) shows some baseline characteristics of the clubs and their members. The first ten variables are measured using the individual survey, and averaged within-club to generate club-level statistics. We surveyed a little less than 12 members per club, for a response rate of over $90 \%$. About $40 \%$ of club members are female. The average age is about 24.5 . About $38 \%$ are currently attending school, with mean educational attainment of the $10^{\text {th }}$-grade. Mean earnings during the last 90 days is about 150,000 UGX, or $120 \%$ of the individual poverty line scaled to 90 days.(Schreiner 2011) We aggregate four proxies for wealth into a mean-zero index, the components of which indicate that mean person in our sample: eats meat 1.7 times per week $(\mathrm{SD}=1.5)$, eats two complete meals per day ( $\mathrm{SD}=0.5)$, lives in a household that owns their home ( $82 \%)$, and has a high-quality latrine (98\%, where high-quality is defined as a covered pit latrine, a covered, ventilated, improved latrine, or a flush toilet). Mean baseline individual savings (i.e., total financial assets) is about 177,000 UGX, and 90,000 UGX after dropping the top $1 \%$ of observations. ${ }^{4}$ Formal bank account ownership

${ }^{4}$ At endline the comparable figure in the control group is about 186,000 UGX (Table 4 Column $6)$. 
is low, about $13 \%$, as is baseline financial knowledge (mean score of about 5.5 correct out of 13 basic questions on the regulation of financial institutions and basic financial concepts like budgeting, interest, and collateral). Trust in the financial system is about 8.7 on a scale of 3 to 12 . The three variables below the trust variable in Table 1 are measured using the club survey, and show that public transport to the district capital is cheap, that most clubs pool some money from club members, but that few clubs have a bank account.

\section{b. Randomization and Balance Checks}

Following the baseline survey, we randomly assigned clubs, 60 each, to control (no treatment), financial education only, account only, or financial education and account. The randomization stratified on region and savings. ${ }^{5}$

Table 1 suggests that baseline club characteristics are balanced across study arms. Columns 1-4 show means and standard errors for the 13 different variables described in Section I-A, separately for each of the four study arms. Column 5 compares these means across the four study arms, separately for each baseline variable, by regressing a baseline variable on the three treatment dummies and stratification variables. Each cell in Column 5 reports the p-value on the F-test of the hypothesis that the three treatment variables are jointly equal to zero. We do not reject that hypothesis for any of the 13 baseline variables. Column 6 tests the joint orthogonality of baseline variables by regressing a binary variable for receiving any treatment on the complete set of baseline variables listed in the rows. Each cell reports the coefficient and standard error, and the second-to-last row of the table reports the result from an f-test of the hypothesis that the baseline variables all equal zero. The p-value is 0.893 , again suggesting that treatment assignment is uncorrelated with the characteristics of clubs and their members.

\footnotetext{
${ }^{5}$ Savings was stratified by binning clubs into those above and below the median total of individual member savings, as self-reported in the baseline survey.
} 


\section{c. Financial Education Treatment}

Innovations for Poverty Action (IPA) developed the financial education course in cooperation with the NGOs Freedom from Hunger and Straight Talk Foundation (STF); STF runs a different network of youth groups throughout Uganda. The course is based on an earlier curriculum by the Global Financial Education Program (GFEP) that targets those near the poverty line in developing countries. GFEP is a strategic partnership between the NGOs Freedom from Hunger and Microfinance Opportunities.

Beginning in July 2010 , the 15 -hour course was delivered over ten weekly meetings. Some clubs scheduled course sessions to piggyback on regular club meeting times; others arranged for separate times. The curriculum focuses on saving, with closely related material on formal financial institutions, budgeting, borrowing, and interest. It covers one topic per meeting: (1) myths about the formal financial sector, (2) bank regulation by the Bank of Uganda, (3) how banks function as businesses, (4) the relative costs and benefits of saving versus borrowing, (5) targeted/goal-oriented saving, (6) budgeting and record keeping, (7) prioritizing spending decisions, (8) addressing challenges to saving, (9) making informed decisions about where and how to save, and (10) how to communicate about money. The pedagogical approach is focused on active and customized learning, with an emphasis on role playing, mini-cases, and group activities. Handouts and homework assignments are used to reinforce each lesson.

IPA hired and trained instructors (with recruiting help from FINCA) who led the classes and tracked attendance. Among those in either of the education treatment arms (education, or education + account), estimated mean attendance is 4.66 sessions, with a standard deviation of 3.86 and a median of $5 .{ }^{6}$ Conditional

\footnotetext{
${ }^{6}$ We calculate attendance rates using the 1,341 endline respondents in the two education study arms in the denominator. See Section I-E for more details on the endline survey.
} 
on attending at least one meeting, the mean attendance was 6.22 and the median was $7.75 \%$ of individuals attended at least one session, and $13 \%$ attended all ten.

\section{d. Savings Account Treatment}

The savings accounts were offered by FINCA, an international microfinance institution, headquartered in the US, with a banking charter in Uganda. IPA and FINCA worked together to design an account that would minimize transaction costs (pecuniary and otherwise), deciding on a group-based account as the most practical way to keep costs down while still enabling FINCA to deliver basic services. Each club had only one account and was responsible for maintaining a ledger with individual members' savings, and selected group members serve as bank field agents for handling deposits and withdrawals. There were no opening or maintenance costs, although clubs were required to make a deposit within thirty days of opening the account and had to maintain a minimum balance of 50,000 UGX.

FINCA began marketing in each of the study regions in November 2010, roughly in accordance with the study design: we encouraged FINCA to begin marketing around the time that the financial education course was concluding. Administrative issues delayed account-opening in the Mbarara district (Western region) until early February; ${ }^{7}$ marketing continued during the delay.

Among clubs assigned to account treatments, an average of 12 club members attended the first account marketing meeting, with a standard deviation of 6.9 and a median of 10.33 percent of those surveyed at baseline attended the first meeting, with no statistically significant difference between those clubs that received financial education and those who did not. Overall, FINCA data shows that 66

\footnotetext{
${ }^{7}$ FINCA required Church authorization to open the accounts, and this authorization too longer than expected to obtain in Mbarara Diocese. Results are similar if we drop the 54 clubs in Mbarara District/Western Region.
} 
percent of clubs offered the account took it up, with no difference in take-up between the account-only and account + education arms.

\section{e. Outcomes from Administrative Bank Data and Endline Surveys}

Administrative bank data show all transactions made by each individual from the time of account opening until July 2011. The latter date was chosen to parallel endline survey data on savings as closely as possible.

Endline surveys were administered between June 15 and August 28, 2011roughly 9-12 months after the completion of financial education, and 7-10 months after the start of account marketing. We attempted to re-survey all baseline survey respondents, using the same surveyors and protocols deployed in the baseline survey. We obtained 2,680 completed endline surveys, for a 95\% retention rate. Appendix Table 1 reconfirms the balance checks from Table 1 on the completedendline survey. Appendix Table 2 shows that retention is uncorrelated with treatment assignment (Columns 1-3), with baseline characteristics (Column 2), or with interactions between treatment arm and baseline characteristics (Column 3). The bottom rows of Appendix Table 2 show the p-values on the requisite F-tests.

\section{f. Estimation Strategy}

We estimate the impacts of financial education and account access by comparing outcomes across treatment arms, and between treatment arms and the control group, using OLS models of the form:

$$
Y_{1 i j}=B_{1} F e A c c t+B_{2} F e+B_{3} A c c t+Y_{0 i j}+\text { StratVars }_{j}+\varepsilon_{i j}
$$

$Y_{1 i j}$ is an outcome variable, for member $i$ of club $j$, in time period 1 (endline) or 0 (baseline). $Y$ takes several different forms: we measure several different types of outcomes using the FINCA data and our endline survey. We measure some of these outcomes as individual variables, and aggregate others into 
standardized indices to mitigate measurement error and multiple hypothesis testing.

The treatment arm variables are FeAcct (financial education + account), $\mathrm{Fe}$ (financial education only), and Acct (account only), with the control group omitted. These variables take the value of 1 if individual $i$ was randomly assigned to that study arm, and 0 otherwise. We use only the random assignment, and thereby identify intent-to-treat (ITT) estimates, because we lack separate instruments for the extensive and intensive margins of the treatments. $B_{1}, B_{2}$ and $B_{3}$ are the ITT point estimates. We cluster standard errors at the unit of randomization: the club. StratVars ${ }_{j}$ is a vector of controls for the randomization stratification variables: region, and above-median club level savings at baseline.

\section{Results: Treatment Effect Estimates}

Each Column in Tables 2-7 presents intent-to-treat estimates from a single OLS regression of an outcome variable on the treatment variables (with the control group as the omitted category), randomization stratification variables, and controls for the baseline value of the dependent variable (where available).

\section{a. On Decision Making Inputs (Table 2)}

We start by estimating treatment effects on directly-elicited measures of various inputs into (financial) decision making: information and decision making ability, plans (financial practices), expectations, and preferences. We elicit these measures using multiple survey questions per input. This multiplicity deals with the likelihoods that some inputs are multi-faceted (e.g., there are probably multiple relevant dimensions of knowledge: e.g., of prices, of contract features, of institutions, etc.), and that many inputs are difficult to measure. We then combine our various measures of an input (the index "component outcomes") into a single index that is meant to summarize that input ("outcome family" in program 
evaluation parlance), scaling each index such that higher values indicate more of the outcome. We standardize each index so that the control group has mean zero and standard deviation one and thus treatment effects are in standard deviation units. $^{8}$ We summarize the content of each index here, and provide surveys used in the Survey Appendix. Appendix Tables 3-15 present treatment effect estimates for each component of each index.

For each outcome family below we summarize related content in the financial education curriculum, to motivate why it is plausible to hypothesize that the education treatment arms might affect that outcome. For most outcomes it is also plausible to hypothesize that the savings account alone has an effect, through the channel of increased market experience. ${ }^{9}$

Table 2 Columns 1-4 present estimates of treatment effects on various measures of how well-informed/skilled/financially literate subjects are. We measure information and skills that were explicitly covered in the financial education course, so it plausible to think that the treatment arms with financial education might have positive effects. One might also acquire information and skills through market experience, so it is also plausible to think that the accountonly treatment arm might have positive effects.

Table 2 Column 1 presents treatment effect estimates on financial knowledge, as measured by an index of 10 questions on bank regulation (e.g,. "what is the name of the government institution of Uganda that regulates formal banks?"; "Is

\footnotetext{
${ }^{8}$ Following standard practice (e.g.,Kling et al (2007)), if we are missing some but not all of the components for an index for the dependent variable, we replace the missing components with the mean of the control group, i.e. zero.

${ }^{9}$ In principle, the account-only treatment could also affect decision inputs through a feedback loop: account $=>$ more wealth $\Rightarrow>$ changes in preferences (e.g., lower risk aversion), expectations, etc. As we discuss below, this sort of loop is not consistent with the full picture of our results. More generally however, the possibility of this sort of feedback (which presumably would take time to materialize), and/or market experience feedback, speaks to the value of measuring inputs at shorter interval(s) post-treatment, before the full causal chain has occurred. Budget constraints however made short-run follow-up surveys infeasible in our case.
} 
Post Bank regulated by the government of Uganda?", etc.) and 7 questions on the definition of basic financial concepts (e.g., budgeting, interest, collateral). The financial education course covered these concepts, and indeed we find a significant 0.08 standard deviation increase in the financial education groups, regardless of whether the savings account was offered as well. Subjects might also learn about these concepts through the experience of saving in a formal account, but we find no evidence of that: the point estimate on the account-only group is -0.01 , and the education-only and account+education treatment effects are nearly identical. Appendix Table 3 presents treatment effect estimates for each component of the knowledge index (after aggregating the 10 regulation questions into a single sub-index).

Table 2 Column 2 presents treatment effect estimates on financial awareness, as measured by an index of 11 questions re: market prices (interest rates on savings and loans, exchange rates, mineral water) and currency ("What is the color of a new 50,000 Shilling note?"; "How can you see if a 20,000 Shilling note is fake...?"). Again this is information that might be gleaned from the financial education course and/or from market experience spurred by the bank account. We find no evidence of significant treatment effects, although the point estimates on the two education groups are positive. Appendix Table 4 presents treatment effect estimates for each component of the awareness index.

Table 2 Column 3 presents treatment effect estimates on numeracy, as measured by one question on addition (that $91 \%$ of respondents answered correctly), one on calculating a percentage (32\% answered correctly), and one on compounding (59\% answered correctly, but it was multiple choice with only two possible answers). We find an increase of 0.05 standard deviations in the education+account treatment group $(\mathrm{p}$-value $=0.077)$. Appendix Table 5 presents treatment effects estimates for each component of the numeracy index. 
Table 2 Column 4 presents estimates on a financial literacy index that combines the knowledge, awareness, and numeracy indices. We find an increase of 0.039 standard deviations in the education-only treatment group (p-value $=$ 0.078), an increase of 0.056 standard deviations in the education+account treatment group $(\mathrm{p}$-value $=0.001)$, and no significant effect in the account-only treatment.

Table 2 Column 5 finds no effects of the treatments on an index of dealing with financial matters at youth club meetings, suggesting that any effects of financial education on financial literacy (components) work through individual learning and not social learning. Appendix Table 6 presents treatment effects estimates for each component of the club financial matters index.

Table 2 Column 6 presents treatment effect estimates on financial planning, as measured by an index of 4 components re: budgeting, tracking, emergency preparation, and follow-through on financial plans. We do not find any significant effects. Appendix Table 7 presents treatment effect estimates for each component of the planning index.

Table 2 Columns 7-12 present treatment effect estimates on measures of preferences and expectations. Many of the financial education lessons illustrate the benefits of patience, and provide tips for controlling spending, so it is plausible to think that education might induce lower discount rates (Column 7) and increase self-control (Column 8). ${ }^{10}$ But we find no significant effects. Appendix Tables 8 and 9 present treatment effect estimates for each component of the discounting and self-control indices.

\footnotetext{
${ }^{10}$ We measure discounting using four standard questions offering smaller-sooner vs. larger-later real-stakes monetary payoffs. We measure self-control using three qualitative questions, and two measures of time-inconsistency based on the real-stakes discounting questions. Stakes took the form of a lottery: there were 13 discounting and risk questions, and the surveyor randomly choose one question per respondent to pay out.
} 
The financial education curriculum might also affect risk tolerance (Column 9 ), in the sense that the curriculum draws attention to various types of risks and the value of preparing for bad shocks. Indeed, we find that both education arms decreased risk tolerance, as measured by eight standard questions, by about 0.06 standard deviations. ${ }^{11}$ There is suggestive evidence that this effect works through a change in expectations rather than in preferences per se. First, as shown below (Table 5), there is some evidence that education treatments increase wealth (or at least income), which would tend to increase risk tolerance under constant relative risk aversion; i.e., the positive treatment effect on income pushes against the negative treatment effect on risk tolerance. Second, point estimates on the treatment effect on the perceived likelihood of a future emergency are positive and relatively large (Table 2 Column 10). But these estimates are noisy because the shock perception index is comprised of only two questions. Appendix Tables 10 and 11 present treatment effect estimates for each component of the risk tolerance and shock perception indices.

Trust in other people and financial institutions might increase as well (Column 11 ), if the educational content on institutional workings and regulation leads people to take a more optimistic view of market interactions. But we do not find any effect on an index of 14 standard questions, and the point estimates are all quite small: around 0.01 standard deviations. Appendix Table 12 presents treatment effect estimates for each component of the trust index. ${ }^{12}$

\footnotetext{
${ }^{11}$ We measure risk tolerance using 7 real-stakes choices (three between two lotteries, one between a risky and an ambiguous lottery, three between a certain option and a lottery), and one lifetime income gamble hypothetical question. Please see the Data Appendix for question scripts. Interestingly, we only see increases in risk aversion for choices where the less-risky option is a certain one, suggesting the financial education increases direct risk aversion (DRA) in particular. See Callen et al (forthcoming) for field evidence on the prevalence of DRA in Afghanistan.

${ }^{12}$ The results on component variables in Appendix Table 12 suggest that there are offsetting effects where the education treatments increase trust in financial institutions (Columns 2 and 3) but decrease trust in other people (note the preponderance of negative point estimates on these variables).
} 
There are two reasons why financial education might decrease altruism. First, the financial education curriculum includes a module on developing social strategies for protecting assets from various external claimants. Second, a key theme of the curriculum is that "anyone can save", which might engender less sympathy for those who do not. Table 2 Column 12 provides some evidence that education does in fact decrease altruism, as measured by an index comprised of responses to one qualitative question and three real-stakes choices in standard social preference elicitations: by 0.06 standard deviations in the education+account arm ( $\mathrm{p}$-value $=0.083)$, and by 0.04 standard deviations in the education-only arm $(p$-value $=0.233)$. In contrast, the account-only arm only reduces altruism by an estimated 0.01 standard deviations ( $p$-value $=0.705$ ). Appendix Table 13 presents treatment effect estimates for each component of the altruism index.

Column 13 shows no effects on financial independence, as measured by an index of one question being financially supported by others, and five questions on financial decision making power/autonomy. Appendix Table 14 presents treatment effect estimates for each component of the financial independence index.

b. On Savings in the Group Account (administrative data, comparing the two arms offered accounts)

Next we compare savings in the group account across the two study arms offered access to the account: account-only vs. account+education. This exercise enables us to estimate whether there is an additive effect of financial education, using data that is free from any self-reporting biases. The downside of course is that the administrative bank data lack information on the other two study arms (the education-only, and control, groups) and on saving in other vehicles (e.g., in other financial institutions, or fixed assets). The next sub-section describes our 
use of survey data to estimate effects using the full sample, and broader measures of savings.

Table 3 shows three important patterns in the administrative bank data. First, most club members do not use the account; we estimate a usage rate of $14 \%$ by dividing the number of depositors in Panel A by the number of club members in Panel B. Second, individuals that do use the account save nontrivial amounts; e.g., about 15,000 UGX in the account-only group (Panel A Column 2). It is important to keep in mind that we measure a stock rather than a flow here, and FINCA savings rather than overall savings, so the effect on total savings could be larger (or smaller). Third, intention-to-treat estimates suggest that financial education has an additive effect on saving in the group account. Panel A Columns 2-6 use individual-level data, on depositors only, and finds that individuals in the account+education group save 4,000-7,000 UGX more than individuals in the account-only group, across a variety of definitions of savings balance. ${ }^{13}$ The effect is statistically significant for four of the five measures of savings, in which cases the implied percentage increase ranges from 58 to 70 percent. Column 1 also shows an effect on the extensive margin (i.e., on the number of members per club who make any deposit), meaning that presence in our depositor-only sample is affected by education. So Panel B repeats Panel A's analysis after adding zeroes for non-depositors. ${ }^{14}$ All five point estimates are positive, three are statistically significant with at least $95 \%$ confidence, and their implied percentage increases range from $75-200 \%$.

\section{c. On Financial Assets and Liabilities (Survey data)}

\footnotetext{
13 The data shows only a snapshot, taken as of July 2011, to match the endline survey timing as closely as possible. Column 2 estimates the treatment effect on level balances, and Columns 3-6 use various top-coding and trimming rules to check for the influence of outliers.

${ }^{14}$ We infer zeros using a measure of the total number of group members from the Club Survey. E.g., if we have a club where we observe 8 depositors in the FINCA data, and 20 members in the club survey, we infer that there are 12 non-depositors, with zero balances, in the FINCA data.
} 
Next we use endline survey data to examine treatment effects on the stock of total savings, using all four study arms.

The first six columns of Table 4 present estimated treatment effects on various measures of total money currently held across all financial savings instruments at the time of the follow-up survey. The survey prompts for 12 such instruments (e.g., "pocket", “an individual account at a formal bank", "other", etc.) We use this data to construct six different measures of total financial savings: any savings (control group mean $=0.84)$, total number of instruments with positive savings (control mean $=1.3$; this is correlated 0.34 with UGX value of total savings and might proxy for diversification as well), UGX value of total savings (control mean $=247,094=\$ 99$ USD), total savings top-coded at the $95^{\text {th }}$ or $99^{\text {th }}$ percentile $($ control means $=162,941$ and $221,940 \mathrm{UGX})$, and total savings dropping the top percentile $($ control mean $=185,740$ UGX).

Qualitatively, we find some evidence that the treatments increased savings relative to the control group. Across the six different measures of savings, all 18 treatment effect point estimates are positive (Table 4 Columns 1-6), and 10 are statistically significant with at least $90 \%$ confidence. Quantitatively, the point estimates from the survey data imply modest effects (1\% to $5 \%)$ on the extensive margin (Column 1), and large effects on the intensive margin of money saved: the estimated increases in total savings (Columns 3-6) are $7 \%$ to $52 \%$ of the control group's savings. ${ }^{15}$

Although the results are statistically stronger for financial education than for the account-- 9 of the 10 statistically significant effects are on the two arms that include financial education, and only one of the account-only treatment effects is

\footnotetext{
${ }^{15}$ To scale by income and thereby infer the effect on individual savings rates, take, e.g., Table 4 Column 4 and compare those treatment effects (roughly 40,000 UGX increase) to the control group's income over the last 90 days in Table 5 Column 2 (180,000 UGX), tripling this income to account for the average time elapsed between treatment and follow-up of 9 months (i.e., assume that savings accumulated over 9 months): 40,000/(180,000x3)= a savings rate increase of roughly $7 \%$.
} 
statistically significant $(\mathrm{p}$-value $=0.074)$-- the table also shows that we cannot reject, statistically speaking, equality between the account-only arm and the education arms. We should also keep in mind that subjects were exposed to the account for less time than to education, due to both the design (which sought to have accounts offered at the conclusion of the 3-month curriculum) and implementation issues (account marketing delays in one of the four regions). This timing issue may weaken our power to identify effects of the account treatment if treatment effects on saving take time to materialize; e.g., if, as hypothesized, they are the result of several months of incremental changes in behavior. Our setup may tilt toward finding larger effects in the education arms, which makes the lack of strong evidence for larger effects all the more striking.

All told, in contrast to the administrative bank data, the endline data shows little evidence of strong complementarity between financial education and account access. Unlike the administrative bank data, we find little evidence of greater saving in the account+education arm than in the account-only arm: the lowest p-value on the six differences is 0.12 , on the extensive margin of money saved (Column 1). Nor do we find strong evidence of greater saving in the account+education arm than in the education-only arm: actually four of the six point estimates are larger for the education-only treatment. Rather, the results support one of two interpretations: (1) education and the account are substitutes for increasing saving; this interpretation focus on the lack of statistically significant differences between the single-treatment arms and the joint-treatment arm; (2) only education is effective at increasing saving; this interpretation focuses on the greater number of statistically significant results in the educationonly arm vs. account-only arm (5 vs. 1).

Appendix Table 15 show results on savings behavior-- deposits, withdrawals, and having a goal - that are consistent with the effects on the stock of financial assets in Table 4 Columns 1-6. Appendix Table 15 shows some evidence of 
increases in regular deposits and having a savings goal (Columns 1 and 3), and no significant effects on making regular withdrawals (with point estimates around zero in Column 2).

The survey has limited data on non-financial assets (e.g,. businesses, livestock), although below we make some inferences below about whether and how the treatments affected investment in non-financial assets through questions on income (Table 5) and expenditures (Table 7).

Table 4 Columns 7-12 present treatment effect estimates on borrowing that parallel those for saving. The motivation for estimating treatment effects on borrowing is twofold: 1) the education curriculum directly discourages borrowing (while presenting saving as a more cost-effective alternative);2) we are interested in testing whether any increased saving is financed by borrowing (as opposed to by reducing expenses and/or increasing income). ${ }^{16}$ We find no evidence of statistically significant treatment effects on borrowing but emphasize that our confidence intervals are wide: these are noisy nulls.

The results thus far suggest that the treatments increase net worth, and the next columns offer a bit of additional support for this inference, examining treatment effects on individuals' evaluations of their current and prospective wealth relative to the rest of their community (individuals rank themselves using a 10-rung ladder). Columns 13 and 14 show that five of the six point estimates are positive, with statistically significant effects on the account+education treatment group. The point estimates imply that any effects are modestly-sized: about half a "rung" or less on the 10-rung ladder (i.e., a shift of $<5$ percentile points in the wealth distribution). The effects on prospective wealth are significantly larger

\footnotetext{
${ }^{16}$ Another possible mechanism is that the treatments help youth claim household assets as their own; i.e., it might be that the treatments merely affect the division of household resources in addition to (or instead of) affect the amount or composition of resources. But the lack of treatment effects on financial independence, including intra-household decision power (Appendix Table 14), casts doubt on the importance of a division/claiming mechanism.
} 
from account+education than from the other treatments, suggesting that financial education and account access might be complements in the long-run even if they are not in the shorter-run.

\section{d. Income and Work}

The large effects on saving motivate estimating treatment effects on income. There are two distinct channels that could produce treatment effects on income as well as on savings. The first channel runs from income to saving: respondents might fund their increased saving by increasing work effort. After all, if they are not increasing borrowing (as suggested by the results in Table 4 Columns 7-12) or increasing their claims on household resources (recall that Table 2 Column 13 finds no effect on financial independence), the only alternative means of increasing saving are earning more (Table 5) or spending less (Table 7). The second channel runs from saving to income: initial increases in saving (over a shorter horizon than our follow-up survey) might fund high-return investments that generate income by the time we conduct our follow-up survey.

Table 5 Columns 1-4 suggest that each of the treatments causes a substantial increase in individually ${ }^{17}$-earned income $(10 \%$ to $15 \%$ over the control mean of total earnings over the last 90 days). ${ }^{18}$ As with the effects on savings, we find no evidence of differential effects across treatment arms, or that financial education and the savings account are complements. Columns 5-16 examine disaggregated

\footnotetext{
${ }^{17}$ We find no effects on club-generating income activities. $48 \%$ of clubs report that they have done some type of activity to generate income for individual club members.

${ }^{18}$ We measured income by asking "We would like to know about what work you did to earn money since 90 DAYS AGO. Have you done any activities to earn any money? This can include small activities or even being given something as a thank-you for work you did" and then, "Please take a moment to think about what work you did to earn money in that time. Please tell me the activities that you got money from in these months", and then asking for various details on each activity, include the amount earned in the past 90 days.
} 
income, from the three most prevalent occupation categories: farming \& livestock rearing, informal employment (e.g., bricklaying, boda/taxi driving), and business ownership. Most of the point estimates are positive, but we do not find statistically robust evidence of increases in any particular category. Column 17 suggests that those in the account+education treatment arm were more likely to be lenders ( 5 percentage points on a base of 71 , $p$-value $=0.074$ ), although Column 18 suggests that even the upper bound of lending's effect on total earnings is likely small. In all, Table 5 shows evidence that each of the treatments increases total earnings, but does not yield strong clues about whether this increase runs from income to saving, or vice versa; e.g., we do not see particularly strong evidence of increases in business earnings that would suggest that initial savings are used to finance productive investments.

Table 6 looks for clues on the mechanism linking savings and income by examining additional measure of work effort. Columns 1 and 2 present estimates of treatment effects on the quantity of work effort. These show no significant effects, although all six point estimates are positive. Columns 3-6 show no significant effects on occupational choice: the likelihood of working in farming/livestock, informal employment, formal employment, or business ownership. Column 7 shows no significant effects on the likelihood of school attendance.

In all, the results on income and work effort yield two main findings: the treatments increase earned income, and our results on income and effort in different types of activities are too imprecise to yield strong clues about the mechanism linking increases in saving with increases in income. Our results are consistent with either or both channels: respondents working more to fund savings, or respondents using initial savings to fund income-generating investments (see also Table 7 Column 9, discussed below). 


\section{e. Expenditures}

Table 7 examines impacts on recent expenditures (with Appendix Table 16 providing some robustness checks re: outliers). Over the roughly nine-month follow-up horizon there are potentially offsetting effects on spending. In the firstorder, the treatments might reduce spending in order to free up money for saving. Higher-frequency and shorter-run follow-ups may be needed to detect such an effect, especially given that the treatments increase income (Table 5), creating the potential for spending increases via an income effect. Indeed, we find no evidence of significant effects on the large expenditures that are measured with six-month look-backs (Columns 7-9) — school fees, health, and business investmentalthough these "nulls" have large confidence intervals. Columns 1-6 focus on very recent expenditure, and hence present a cleaner test of the income effect. The only significant effects suggest an increase in the consumption of meat, which is thought to be a very income-elastic good.

In all, we find little of evidence of treatment effects on expenditure, although it is important to keep in mind that our nulls are imprecisely estimated. It may also be the case that our estimated null results obscure offsetting substitution and income effects.

\section{f. Reporting Bias?}

Are the estimates of large treatment effects on saving artifacts of reporting bias (e.g., experimenter demand effects)? After all, each of the three treatment arms was encouraged to save - through the financial education curriculum and/or marketing of the savings account-so it is reasonable to wonder whether individuals assigned to treatment might simply report more savings due to image concerns. In our view two factors push against the reporting bias interpretation. First, we find a treatment effect in administrative data that is unaffected by reporting bias concerns (Section II-B and Table 3). Second, we find treatment 
effects on income as well as on saving, and the treatments did not emphasize income generation.

\section{Conclusion}

Microfinance increasingly focuses on encouraging savings, especially among youth. We develop some evidence on whether and why two common approaches to encouraging saving-expanding basic account access and financial education - are (in)effective, using a 2x2 field experiment among 240 Ugandan youth clubs.

We find significant treatment effects on financial knowledge and other inputs to decision making for those in the two financial education treatment groups relative to the control group, but not for those who only received simplified access to subsidized group savings accounts. We also find a significant increase in savings for the education groups; the point estimate for the account-only group is positive but not significantly different from either the control group or those in the other treatment arms. All three treatment groups report significantly higher earned income than the control group, at roughly equal levels.

Our results come with several caveats. We lack data on some key mechanisms; e.g., on how much of the savings increase is in formal versus informal vehicles, and on whether savings leads to higher income via motivation and/or productive investments. We also lack data to measure whether the treatment effects persist over longer horizons. This is clearly critical to the motivation, and policy focus, on youth financial education and access.

The question of whether expanding account access and financial education are complements or substitutes is a critical one given the relatively high cost of financial education as typically delivered (i.e., in a labor intense way). One could reasonably infer from our results that increased knowledge is not a necessary condition for increasing saving or income, and hence that account access and 
financial education are substitutes. This interpretation focuses on the findings of: 1) knowledge increases in the education groups but not in the account-only groups; 2) similar effects on saving in the account-only and education treatments; 3) similar increases in earned income in the account-only and education treatments. Under this interpretation one might elect to pursue only the lower-cost of the two interventions, and/or to invest in developing and evaluating lower-cost delivery approaches (e.g., through mobile platforms). On the other hand, one might reasonably ask whether our data are rich enough, or results precise enough, to detect higher savings in the education+account group versus the account-only group (as suggested by the bank administrative data and some of the point estimates in the survey data), and/or all of the downstream effects of increased knowledge (e.g., on unmeasured or longer-term outcomes). This highlights the value of further work to pin down the mechanisms underlying pro-savings and other anti-poverty interventions. 


\section{References}

Ashraf, Nava, Dean Karlan, and Wesley Yin. 2006. "Tying Odysseus to the Mast: Evidence from a Commitment Savings Product in the Philippines." Quarterly Journal of Economics 121 (2): 673-97.

- 2010. "Female Empowerment: Further Evidence from a Commitment Savings Product in the Philippines." World Development 38 (3): 333-44.

Banerjee, Abhijit. 2013. "Microcredit Under the Microscope: What Have We Learnt in the Last Two Decades, What Do We Need to Know?" Annual Review of Economics 5: 487-519.

Banerjee, Abhijit, and Esther Duflo. 2007. "The Economic Lives of the Poor." Journal of Economic Perspectives 21 (1).

Bruhn, Miriam, Luciana de Souza Leão, Arianna Legovini, Rogelio Marchetti, and Bilal Zia. 2013. "Can High School Financial Education Improve Economic Preferences and Outcomes? Evidence from Brazil." World Bank Working Paper.

Brune, Lasse, Xavier Giné, Jessica Goldberg, and Dean Yang. 2013. "Commitments to Save: A Field Experiment in Rural Malawi."

Burgess, Robin, and Rohini Pande. 2005. "Do Rural Banks Matter? Evidence from the Indian Social Banking Experiment." American Economic Review 95 (3): 780-95.

Callen, Michael, Isaqzadeh, Mohammed, Long, James, and Sprenger, Charles. forthcoming. "Violence and Risk Preferences: Artefactual and Experimental Evidence from Afghanistan." American Economic Review

Cole, Shawn, Thomas Sampson, and Bilal Zia. 2011. "Prices or Knowledge? What Drives Demand for Financial Services in Emerging Markets?" Journal of Finance 66 (6): 1933-67.

Collins, Daryl, Jonathan Morduch, Stuart Rutherford, and Orlanda Ruthven. 2009. Portfolios of the Poor: How the World's Poor Live on \$2 a Day. Princeton University Press.

Demirguc-Kunt, Asli, and Leora Klapper. 2012. "Measuring Financial Inclusion: The Global Findex Database." World Bank Working Paper.

Dupas, Pascaline, and Jonathan Robinson. 2013a. "Savings Constraints and Microenterprise Development: Evidence from a Field Experiment in Kenya." American Economic Journal: Applied Economics 5 (1): 163-92. doi:10.1257/app.5.1.163. . 2013b. "Why Don't the Poor Save More? Evidence from Health Savings Experiments." The American Economic Review 103 (4): 1138-71. 
Fernandes, Daniel, John G. Lynch, and Richard G. Netemeyer. 2013. "Financial Literacy, Financial Education and Downstream Financial Behaviors." Management Science forthcoming (October).

Hastings, Justine S., Brigitte C. Madrian, and William L. Skimmyhorn. 2013. "Financial Literacy, Financial Education, and Economic Outcomes." Annual Review of Economics 5 (1): 347-73. doi:10.1146/annureveconomics-082312-125807.

Karlan, Dean, Aishwarya Ratan, and Jonathan Zinman. 2013. "Savings by and for the Poor: A Research Review and Agenda." Review of Income and Wealth, October.

Kling, Jeffrey, Jeffrey Liebman, and Lawrence Katz. 2007. "Experimental Analysis of Neighborhood Effects." Econometrica 75 (1): 83-120.

Miller, Margaret, Julia Reichelstein, Christian Salas, and Bilal Zia. 2013. "Can You Help Someone Become Financially Capable? A Meta-Analysis of the Literature."

Prina, Silvia. 2013. "Banking the Poor via Savings Accounts: Evidence from a Field Experiment." Working Paper, May.

Rutherford, Stuart. 2000. The Poor and Their Money. New Delhi: Oxford University Press.

Schaner, Simone. 2013. "The Persistent Power of Behavioral Change: Long-Run Impacts of Temporary Savings Subsidies for the Poor."

Schreiner, Mark. 2011. "Progress out of Poverty Index (PPI) A Simple Poverty Scorecard for Uganda". Grameen Foundation.

$\mathrm{Xu}$, Lisa, and Bilal Zia. 2012. "Financial Literacy Around the World: An Overview of the Evidence with Practical Suggestions for the Way Forward”. 6107. World Bank Policy Research Working Paper. World Bank. 
Table 1: Baseline Club Characteristics by Study Arm

\begin{tabular}{|c|c|c|c|c|c|c|}
\hline & $\begin{array}{c}(1) \\
\text { Account } \\
\text { Only }\end{array}$ & $\begin{array}{c}(2) \\
\text { Education } \\
\text { Only }\end{array}$ & $\begin{array}{c}\text { (3) } \\
\text { Account + } \\
\text { Education }\end{array}$ & Control & $\begin{array}{l}(5) \\
\text { p-value from f-test } \\
\text { from regressing row } \\
\text { var on indicators for } \\
\text { each treatment }\end{array}$ & $\begin{array}{c}(6) \\
\text { p-value from f-test } \\
\text { from regressing row } \\
\text { variable on indicator } \\
\text { for any treatment }\end{array}$ \\
\hline $\begin{array}{l}\text { Count of Baseline Survey } \\
\text { Respondents }\end{array}$ & $\begin{array}{c}11.80 \\
(0.184)\end{array}$ & $\begin{array}{c}11.53 \\
(0.192)\end{array}$ & $\begin{array}{c}11.55 \\
(0.172)\end{array}$ & $\begin{array}{c}11.95 \\
(0.147)\end{array}$ & 0.263 & 0.111 \\
\hline Proportion of Female Club Members & $\begin{array}{c}0.425 \\
(0.0237)\end{array}$ & $\begin{array}{c}0.409 \\
(0.0194)\end{array}$ & $\begin{array}{c}0.423 \\
(0.0204)\end{array}$ & $\begin{array}{c}0.443 \\
(0.0224)\end{array}$ & 0.737 & 0.332 \\
\hline Has Any Formal Account & $\begin{array}{c}0.121 \\
(0.0188)\end{array}$ & $\begin{array}{c}0.126 \\
(0.0179)\end{array}$ & $\begin{array}{c}0.174 \\
(0.0230)\end{array}$ & $\begin{array}{c}0.132 \\
(0.0190)\end{array}$ & 0.214 & 0.712 \\
\hline $\begin{array}{l}\text { Financial Knowledge Score (\# of } \\
\text { questions answered correctly of } 13 \text { ) }\end{array}$ & $\begin{array}{c}5.664 \\
(0.158)\end{array}$ & $\begin{array}{c}5.406 \\
(0.158)\end{array}$ & $\begin{array}{c}5.713 \\
(0.165)\end{array}$ & $\begin{array}{l}5.670 \\
(0.173)\end{array}$ & 0.532 & 0.687 \\
\hline $\begin{array}{l}\text { Trust in Financial System on scale of } \\
3 \text { (least) to } 12 \text { (most) }\end{array}$ & $\begin{array}{c}8.731 \\
(0.106)\end{array}$ & $\begin{array}{c}8.681 \\
(0.0847)\end{array}$ & $\begin{array}{c}8.699 \\
(0.111)\end{array}$ & $\begin{array}{l}8.723 \\
(0.103)\end{array}$ & 0.985 & 0.868 \\
\hline Age & $\begin{array}{l}24.66 \\
(0.453)\end{array}$ & $\begin{array}{c}24.56 \\
(0.469)\end{array}$ & $\begin{array}{c}24.65 \\
(0.445)\end{array}$ & $\begin{array}{c}24.27 \\
(0.438)\end{array}$ & 0.922 & 0.498 \\
\hline Currently in school & $\begin{array}{c}0.366 \\
(0.0304)\end{array}$ & $\begin{array}{c}0.394 \\
(0.0297)\end{array}$ & $\begin{array}{c}0.377 \\
(0.0292)\end{array}$ & $\begin{array}{c}0.391 \\
(0.0278)\end{array}$ & 0.895 & 0.717 \\
\hline Education: Highest Grade Completed & $\begin{array}{c}10.24 \\
(0.255)\end{array}$ & $\begin{array}{c}10.12 \\
(0.226)\end{array}$ & $\begin{array}{l}10.50 \\
(0.261)\end{array}$ & $\begin{array}{l}10.30 \\
(0.241)\end{array}$ & 0.741 & 0.959 \\
\hline $\begin{array}{l}\text { Income: total last } 90 \text { days ('000 } \\
\text { UGX) }\end{array}$ & $\begin{array}{l}146.7 \\
(11.82)\end{array}$ & $\begin{array}{l}146.0 \\
(14.24)\end{array}$ & $\begin{array}{c}168.8 \\
(13.33)\end{array}$ & $\begin{array}{c}141.3 \\
(13.88)\end{array}$ & 0.47 & 0.417 \\
\hline Wealth Index & $\begin{array}{c}0.0228 \\
(0.0742)\end{array}$ & $\begin{array}{l}-0.0728 \\
(0.0533)\end{array}$ & $\begin{array}{l}0.00596 \\
(0.0726)\end{array}$ & $\begin{array}{l}-0.0352 \\
(0.0624)\end{array}$ & 0.739 & 0.789 \\
\hline $\begin{array}{l}\text { Cost to Reach District Capital by } \\
\text { Public Transport ('000 UGX) }\end{array}$ & $\begin{array}{c}4.364 \\
(0.354)\end{array}$ & $\begin{array}{c}4.918 \\
(0.579)\end{array}$ & $\begin{array}{c}4.193 \\
(0.396)\end{array}$ & $\begin{array}{c}4.422 \\
(0.457)\end{array}$ & 0.704 & 0.894 \\
\hline Whether Club Has Money & $\begin{array}{c}0.817 \\
(0.0504)\end{array}$ & $\begin{array}{c}0.695 \\
(0.0605)\end{array}$ & $\begin{array}{c}0.767 \\
(0.0551)\end{array}$ & $\begin{array}{c}0.833 \\
(0.0485)\end{array}$ & 0.277 & 0.237 \\
\hline Whether Club Has Bank Account & $\begin{array}{c}0.0667 \\
(0.0325)\end{array}$ & $\begin{array}{c}0.0500 \\
(0.0284)\end{array}$ & $\begin{array}{c}0.0833 \\
(0.0360)\end{array}$ & $\begin{array}{c}0.0667 \\
(0.0325)\end{array}$ & 0.913 & 1.000 \\
\hline $\begin{array}{l}\text { Stratification Variables: } \\
\text { Average Savings of All Members by } \\
\text { Club ('000 UGX) }\end{array}$ & $\begin{array}{c}82.69 \\
(9.166)\end{array}$ & $\begin{array}{c}103.7 \\
(12.31)\end{array}$ & $\begin{array}{c}84.99 \\
(9.538)\end{array}$ & $\begin{array}{c}91.40 \\
(5.258)\end{array}$ & 0.478 & 0.758 \\
\hline Region: North & $\begin{array}{c}0.250 \\
(0.0564)\end{array}$ & $\begin{array}{c}0.283 \\
(0.0587)\end{array}$ & $\begin{array}{c}0.283 \\
(0.0587)\end{array}$ & $\begin{array}{c}0.271 \\
(0.0287)\end{array}$ & 0.973 & 0.934 \\
\hline Region: East & $\begin{array}{c}0.300 \\
(0.0597)\end{array}$ & $\begin{array}{c}0.283 \\
(0.0587)\end{array}$ & $\begin{array}{c}0.267 \\
(0.0576)\end{array}$ & $\begin{array}{c}0.279 \\
(0.0290)\end{array}$ & 0.974 & 0.804 \\
\hline Region: West & $\begin{array}{c}0.183 \\
(0.0504)\end{array}$ & $\begin{array}{c}0.167 \\
(0.0485)\end{array}$ & $\begin{array}{c}0.183 \\
(0.0504)\end{array}$ & $\begin{array}{c}0.183 \\
(0.0250)\end{array}$ & 0.974 & 0.701 \\
\hline Region: Central & $\begin{array}{c}0.267 \\
(0.0576)\end{array}$ & $\begin{array}{c}0.267 \\
(0.0576)\end{array}$ & $\begin{array}{c}0.267 \\
(0.0576)\end{array}$ & $\begin{array}{c}0.267 \\
(0.0286)\end{array}$ & 1.000 & 1.000 \\
\hline Number of Clubs & 60 & 60 & 60 & 60 & 240 & 240 \\
\hline
\end{tabular}

Notes: Means, with standard errors in parentheses, unless otherwise noted. All variables are club-level averages of individual respondents to the baseline survey, except for the transport, club money, and club bank account variables, which are measured using the club survey. The binary indicator for whether a club has money or not has one missing value in the "Account Only" treatment. Each cell in Column 5 provides the p-value from an F-test on the joint signifiance of the three treatment variables, from an OLS regression of the row variable on the treatment. Each cell in Column 6 presents the p-values from an F-test on the significance of any treatment, from an OLS regression of the row variable on the treatment.

Variable Definitions: Formal account includes group and/or individual accounts; Financial Knowledge: 13 questions on definitions of basic financial terrms (e.g., budgeting, interest, collateral) and the regulation of financial institutions; Trust in financial system: three questions re: theft/expropriation risk at banks; Age and income exclude the top 1\% of individual-level observations; Wealth Index: standardized at the individual-level and based on responses to 4 questions re: meat-eating, number of meals, homeownership, and toilet facilities; Cost to reach district capital: Average of up to 5 individual responses from the Club Survey; Whether Club Has Money: From Club Survey question asking whether club has collective money; Whether Club Has Bank Account: From Club Survey question asking whether club has a formal bank account. 
Table 2: Treatment Effects on Inputs to Decision Making Regressions of Standardized Indices on Treatment Variables and Controls

\begin{tabular}{|c|c|c|c|c|c|c|}
\hline & LHS: & $\begin{array}{c}(1) \\
\text { Financial } \\
\text { Knowledge } \\
\text { Questions }\end{array}$ & $\begin{array}{c}\text { (2) } \\
\text { Financial } \\
\text { Awareness }\end{array}$ & Numeracy & $\begin{array}{c}\text { (4) } \\
\text { Financial } \\
\text { Literacy }\end{array}$ & $\begin{array}{c}\text { (5) } \\
\text { Financial } \\
\text { Matters at Club } \\
\text { Meetings }\end{array}$ \\
\hline Account Only & & $\begin{array}{l}-0.009 \\
(0.028)\end{array}$ & $\begin{array}{l}-0.022 \\
(0.024)\end{array}$ & $\begin{array}{l}-0.008 \\
(0.029)\end{array}$ & $\begin{array}{l}-0.020 \\
(0.022)\end{array}$ & $\begin{array}{c}0.051 \\
(0.042)\end{array}$ \\
\hline Education Only & & $\begin{array}{c}0.085^{* * *} \\
(0.028)\end{array}$ & $\begin{array}{c}0.018 \\
(0.024)\end{array}$ & $\begin{array}{c}0.009 \\
(0.030)\end{array}$ & $\begin{array}{l}0.039^{*} \\
(0.022)\end{array}$ & $\begin{array}{l}-0.009 \\
(0.040)\end{array}$ \\
\hline Account + Education & & $\begin{array}{c}0.084^{* * * *} \\
(0.028)\end{array}$ & $\begin{array}{c}0.036 \\
(0.024)\end{array}$ & $\begin{array}{l}0.048^{*} \\
(0.027)\end{array}$ & $\begin{array}{c}0.056^{* * *} \\
(0.021)\end{array}$ & $\begin{array}{c}0.015 \\
(0.037)\end{array}$ \\
\hline Controls for Baseline Values & & No & No & Yes & No & Yes \\
\hline $\mathrm{N}$ baseline miss val & & 0 & 0 & 0 & 0 & 0 \\
\hline Observations & & 2680 & 2680 & 2680 & 2680 & 2680 \\
\hline Control Mean & & 0.000 & 0.000 & 0.000 & 0.000 & 0.000 \\
\hline Std. Dev & & 0.423 & 0.370 & 0.607 & 0.337 & 0.675 \\
\hline F-test (p-value): Acct $=$ Acct $+E d$ & & $12.28(0.00)$ & $4.90(0.03)$ & $3.26(0.07)$ & $11.10(0.00)$ & $1.04(0.31)$ \\
\hline F-test (p-value): $E d=A c c t+E d$ & & $0.00(0.97)$ & $0.48(0.49)$ & $1.53(0.22)$ & $0.55(0.46)$ & $0.49(0.49)$ \\
\hline F-test (p-value): Acct $=E d$ & & $12.33(0.00)$ & $2.41(0.12)$ & $0.24(0.62)$ & $6.22(0.01)$ & $2.30(0.13)$ \\
\hline Proportion of Obs Equal Zero & & 0.00 & 0.00 & 0.00 & 0.00 & 0.00 \\
\hline
\end{tabular}

Notes: ${ }^{*}$ significant at $10 \%,{ }^{* *}$ significant at $5 \%,{ }^{* * *}$ significant at $1 \%$. OLS intent-to-treat estimates, with standard errors in parenthesis, clustered at the unit of randomization (the youth club). Sample contains 2680 respondents present for both the baseline and followup surveys. Each column reports results for a single OLS regression of the dependent variable listed in the column heading on the treatment variables listed in the row headings (control group is the omitted category), the baseline value of the dependent outcome variable if available (with a dummy for missing baseline value where needed), and the stratification variables for randomization (not shown in table): average savings per club member at time of baseline, and region. Each dependent variable is a index of several related questions ("component outcomes", indexed to form an "outcome family"). Each index is standardized so the control group has a mean of zero and a standard deviation of one. A missing value for a component outcome is replaced with the control group mean. We briefly summarize index components on the next page and provide details in the below-referenced Appendix Tables and the Data Appendix. 
Table 2 (cont): Treatment Effects on Inputs to Decision Making Regressions of Standardized Indices on Treatment Variables and Controls

\begin{tabular}{|c|c|c|c|c|c|c|c|}
\hline (6) & (7) & (8) & (9) & (10) & (11) & (12) & (13) \\
\hline $\begin{array}{l}\text { Financial } \\
\text { Planning }\end{array}$ & Discounting & Self Control & Risk Tolerance & $\begin{array}{c}\text { Likelihood of } \\
\text { Bad Shock }\end{array}$ & Trust & Altruism & $\begin{array}{c}\text { Financial } \\
\text { Independence } \\
\text { Index }\end{array}$ \\
\hline 0.022 & 0.017 & 0.011 & 0.001 & 0.079 & 0.011 & -0.014 & -0.022 \\
\hline$(0.033)$ & $(0.028)$ & $(0.025)$ & $(0.033)$ & $(0.052)$ & $(0.022)$ & $(0.036)$ & $(0.036)$ \\
\hline 0.048 & -0.012 & 0.009 & $-0.068 * *$ & 0.050 & -0.007 & -0.039 & 0.019 \\
\hline$(0.032)$ & $(0.029)$ & $(0.023)$ & $(0.033)$ & $(0.057)$ & $(0.022)$ & $(0.033)$ & $(0.033)$ \\
\hline-0.026 & -0.014 & 0.034 & $-0.061 *$ & 0.075 & 0.010 & $-0.057^{*}$ & 0.029 \\
\hline$(0.032)$ & $(0.030)$ & $(0.023)$ & $(0.033)$ & $(0.051)$ & $(0.022)$ & $(0.033)$ & $(0.035)$ \\
\hline No & Yes & No & No & No & No & No & No \\
\hline 0 & 0 & 0 & 0 & 0 & 0 & 0 & 0 \\
\hline 2680 & 2680 & 2680 & 2680 & 2680 & 2680 & 2680 & 2680 \\
\hline 0.000 & 0.000 & 0.000 & 0.000 & 0.000 & 0.000 & 0.000 & 0.000 \\
\hline 0.533 & 0.517 & 0.464 & 0.554 & 0.900 & 0.364 & 0.531 & 0.548 \\
\hline $1.91(0.17)$ & $1.17(0.28)$ & $0.82(0.37)$ & $3.30(0.07)$ & $0.01(0.93)$ & $0.00(0.98)$ & $1.49(0.22)$ & $1.80(0.18)$ \\
\hline $4.69(0.03)$ & $0.00(0.95)$ & $1.10(0.29)$ & $0.05(0.83)$ & $0.24(0.62)$ & $0.64(0.43)$ & $0.30(0.58)$ & $0.08(0.77)$ \\
\hline $0.52(0.47)$ & $1.12(0.29)$ & $0.01(0.93)$ & $3.96(0.05)$ & $0.32(0.57)$ & $0.66(0.42)$ & $0.51(0.48)$ & $1.35(0.25)$ \\
\hline 0.00 & 0.00 & 0.00 & 0.00 & 0.00 & 0.00 & 0.00 & 0.00 \\
\hline
\end{tabular}

Index Components:

(1) Financial Knowledge: 17 questions on whether various financial institutions in Uganda are regulated and the definitions of simple financial terms like budgeting, interest, and collateral (see Appendix Table 3).

(2) Financial Awareness: 11 questions about market prices and currency characteristics (see Appendix Table 4).

(3) Numeracy: 3 questions re: simple addition, percentage, and the concept of compound growth (see Appendix Table 5).

(4) Financial Literacy: Composite of columns 1-3.

(5) Financial Matters at Club Meetings: 3 questions about the extent to which money related matters are discussed in respondent's youth group (see Appendix Table 6).

(6) Financial Planning: 4 questions about whether a respondent keeps track of their monetary expenses or makes plans for using money they receive (see Appendix Table 7).

(7) Time Discounting: 4 real-stakes choices between money now and money in the future (see Appendix Table 8).

(8) Self Control: 3 qualitative questions re: procrastination and spending money too quickly or without thinking, and two measures of time-inconsistency based on the real-stakes discounting questions (see Appendix Table 9).

(9) Risk Tolerance: based on 7 real-stakes choices (three between two lotteries, one between a risky and an ambiguous lottery, three between a certain option and a lottery), and one lifetime income gamble hypothetical question (see Appendix Table 10).

(10) Shock Perceptions: 2 questions about whether the respondent thinks they are likely to be effected by a negative shock in the next 3 or 6 months (see Appendix Table 11).

(11) Trust: 14 standard hypothetical questions about trust in financial institutions and in other people (see Appendix Table 12).

(12) Altruism: one qualitative question and three real-stakes choices in standard social preference elicitations (see Appendix Table 13)

(13) Financial Independence: one question being financially supported by others, and five questions on financial decision making power/autonomy (see Appendix Table 14). 
Table 3: Treatment Effects on Savings in the Group Account: Administrative Data

Sample Frame: Account Treatment Groups Only

\begin{tabular}{|c|c|c|c|c|c|c|c|}
\hline & $(1)$ & (2) & (3) & (4) & (5) & (6) & (7) \\
\hline LHS: & $\begin{array}{c}\text { Number of } \\
\text { Members Who } \\
\text { Made Deposits } \\
\text { per Club }\end{array}$ & $\begin{array}{c}\text { Recorded } \\
\text { Making any } \\
\text { Deposit }\end{array}$ & $\begin{array}{c}\text { Balance ('000 } \\
\text { UGX) }\end{array}$ & $\begin{array}{c}\text { Balance: } 95 \% \\
\text { Winsor ('000 } \\
\text { UGX) }\end{array}$ & $\begin{array}{c}\text { Balance: } 99 \% \\
\text { Winsor ('000 } \\
\text { UGX) }\end{array}$ & $\begin{array}{c}\text { Balance: } 95 \% \\
\text { Trim ('000 } \\
\text { UGX) }\end{array}$ & $\begin{array}{c}\text { Balance: } 99 \% \\
\text { Trim ('000 } \\
\text { UGX) }\end{array}$ \\
\hline \multicolumn{8}{|c|}{ Panel A: Administrative Data with Depositors Only } \\
\hline Account + Education & $2.610^{*}$ & & -0.395 & $4.577 * *$ & $6.775^{*}$ & $3.481 * *$ & $5.292 * *$ \\
\hline (omitted = Account Only) & $(1.418)$ & & $(11.289)$ & $(2.003)$ & $(3.978)$ & $(1.675)$ & $(2.479)$ \\
\hline Mean of Account Only Treatment & 3.767 & & 15.291 & 7.625 & 9.695 & 5.986 & 8.741 \\
\hline Observations & 120 & & 544 & 544 & 544 & 518 & 539 \\
\hline \multicolumn{8}{|c|}{ Panel B: Administrative Data with Zeros Imputed } \\
\hline Account + Education & & 0.073 & 1.213 & $0.645^{* *}$ & $1.238^{* *}$ & 0.107 & $1.054 * *$ \\
\hline (omitted = Account Only) & & $(0.047)$ & $(1.018)$ & $(0.289)$ & $(0.534)$ & $(0.125)$ & $(0.447)$ \\
\hline Mean of Account Only Treatment & & 0.103 & 1.606 & 0.441 & 0.736 & 0.260 & 0.489 \\
\hline Observations & & 3775 & 3775 & 3775 & 3775 & 3587 & 3738 \\
\hline
\end{tabular}

Notes: * significant at 10\%, ** significant at 5\%,*** significant at $1 \%$. OLS intent-to-treat estimates, with standard errors in parenthesis, clustered at the unit of

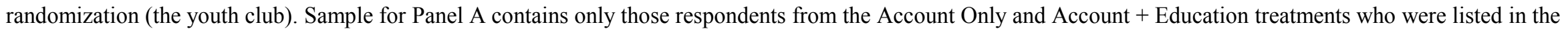

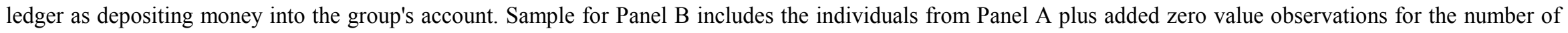

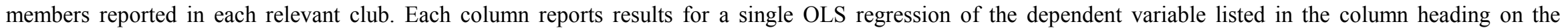

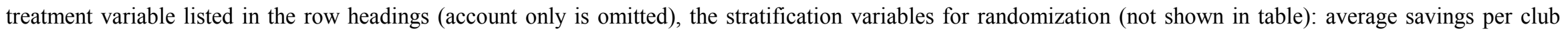
member at time of baseline, and region. Balances are measured in a single snapshot taken in July 2011 to match the timing of the endline survey as closely as possible.

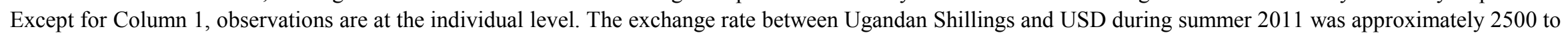
1. 
Table 4: Treatment Effects on Financial Assets and Liabilities ('000 UGX): Self-Report from Survey

\begin{tabular}{|c|c|c|c|c|c|c|}
\hline & (1) & (2) & (3) & (4) & (5) & (6) \\
\hline LHS: & $\begin{array}{l}\text { Any Money } \\
\text { Saved }\end{array}$ & $\begin{array}{l}\text { Total number } \\
\text { of Savings } \\
\text { Instruments }\end{array}$ & Total Savings & $\begin{array}{l}\text { Total Savings: } \\
\text { topcode top 5\% }\end{array}$ & $\begin{array}{l}\text { Total Savings: } \\
\text { topcode top } 1 \%\end{array}$ & $\begin{array}{l}\text { Total Savings: } \\
\text { drop top } 1 \%\end{array}$ \\
\hline \multirow[t]{2}{*}{ Account Only } & 0.008 & $0.098^{*}$ & 52.780 & 24.329 & 48.754 & 22.788 \\
\hline & $(0.023)$ & $(0.055)$ & $(55.161)$ & $(16.788)$ & $(37.858)$ & $(26.348)$ \\
\hline \multirow[t]{2}{*}{ Education Only } & 0.022 & $0.147 * *$ & $127.949 * *$ & $48.663 * * *$ & $101.844 * *$ & $56.611 *$ \\
\hline & $(0.020)$ & $(0.059)$ & $(61.957)$ & $(17.873)$ & $(41.572)$ & $(30.023)$ \\
\hline \multirow[t]{2}{*}{ Account + Education } & $0.042 * *$ & $0.148 * * *$ & 17.834 & $39.592 * *$ & 47.354 & $52.271 *$ \\
\hline & $(0.019)$ & $(0.057)$ & $(46.047)$ & $(17.254)$ & $(34.637)$ & $(27.937)$ \\
\hline Controls for Baseline Values & Yes & Yes & Yes & Yes & Yes & Yes \\
\hline $\mathrm{N}$ baseline miss val & 0 & 0 & 4.000 & 4.000 & 4.000 & 0.000 \\
\hline Observations & 2680 & 2680 & 2678 & 2678 & 2678 & 2647 \\
\hline Control Mean & 0.839 & 1.276 & 247.094 & 162.941 & 221.940 & 185.740 \\
\hline Std. Dev & 0.368 & 0.876 & 867.992 & 296.602 & 606.003 & 438.797 \\
\hline F-test (p-value): Acct $=$ Acct + Ed & $2.47(0.12)$ & $0.89(0.35)$ & $0.63(0.43)$ & $0.87(0.35)$ & $0.00(0.97)$ & $1.54(0.22)$ \\
\hline F-test (p-value): $E d=$ Acct $+E d$ & $1.31(0.25)$ & $0.00(0.98)$ & $4.64(0.03)$ & $0.27(0.60)$ & $2.27(0.13)$ & $0.03(0.87)$ \\
\hline F-test (p-value): Acct $=E d$ & $0.34(0.56)$ & $0.81(0.37)$ & $1.55(0.21)$ & $2.09(0.15)$ & $1.83(0.18)$ & $1.74(0.19)$ \\
\hline Proportion of Obs Equal Zero & 0.143 & 0.142 & 0.145 & 0.145 & 0.145 & 0.146 \\
\hline
\end{tabular}


Table 4 (cont): Treatment Effects on Financial Assets and Liabilities: Self-Report from Survey

\begin{tabular}{|c|c|c|c|c|c|c|c|}
\hline (7) & (8) & (9) & (10) & (11) & (12) & (13) & (14) \\
\hline $\begin{array}{l}\text { Borrowed Any } \\
\text { Money (past } 6 \\
\text { months) }\end{array}$ & $\begin{array}{c}\text { \# of Times } \\
\text { Borrowed } \\
\text { Money (past } 6 \\
\text { months) }\end{array}$ & $\begin{array}{l}\text { Total Amount } \\
\text { Borrowed (past } \\
6 \text { months) }\end{array}$ & $\begin{array}{l}\text { Total Amount } \\
\text { Borrowed: } \\
\text { topcode top 5\% }\end{array}$ & $\begin{array}{l}\text { Total Amount } \\
\text { Borrowed: } \\
\text { topcode top 1\% }\end{array}$ & $\begin{array}{l}\text { Total Borrowed: } \\
\text { drop top } 1 \%\end{array}$ & $\begin{array}{c}\text { Wealth } \\
\text { Compared to } \\
\text { Community: } \\
\text { Current }\end{array}$ & $\begin{array}{c}\text { Wealth } \\
\text { Compared to } \\
\text { Community: } \\
\text { Future } \\
\end{array}$ \\
\hline-0.043 & 0.002 & 21.763 & -1.783 & -5.832 & -3.711 & 0.139 & 0.088 \\
\hline$(0.027)$ & $(0.053)$ & $(29.271)$ & (4.544) & $(10.160)$ & (7.832) & $(0.124)$ & $(0.134)$ \\
\hline-0.042 & -0.041 & 6.971 & -1.025 & 4.552 & -6.065 & 0.127 & -0.006 \\
\hline$(0.026)$ & $(0.052)$ & $(12.935)$ & $(4.092)$ & $(10.351)$ & $(7.284)$ & $(0.126)$ & $(0.136)$ \\
\hline-0.034 & -0.020 & 22.883 & 2.346 & 2.523 & -4.156 & $0.276^{* *}$ & $0.342 * * *$ \\
\hline$(0.030)$ & $(0.055)$ & (18.349) & $(4.585)$ & $(9.888)$ & (7.077) & $(0.120)$ & $(0.129)$ \\
\hline Yes & Yes & Yes & Yes & Yes & Yes & Yes & Yes \\
\hline 3.000 & 0.000 & 0.000 & 0.000 & 0.000 & 0.000 & 0 & 0 \\
\hline 2680 & 2680 & 2678 & 2678 & 2678 & 2648 & 2680 & 2680 \\
\hline 0.522 & 0.758 & 63.387 & 37.377 & 62.604 & 49.751 & 3.854 & 7.307 \\
\hline 0.500 & 0.905 & 203.572 & 77.762 & 197.020 & 143.167 & 2.002 & 2.113 \\
\hline $0.08(0.78)$ & $0.17(0.68)$ & $0.00(0.97)$ & $0.75(0.39)$ & $0.67(0.42)$ & $0.00(0.95)$ & $1.16(0.28)$ & $3.67(0.06)$ \\
\hline $0.07(0.79)$ & $0.14(0.71)$ & $0.56(0.45)$ & $0.61(0.44)$ & $0.04(0.84)$ & $0.07(0.78)$ & $1.32(0.25)$ & $6.80(0.01)$ \\
\hline $0.00(0.97)$ & $0.71(0.40)$ & $0.23(0.63)$ & $0.03(0.86)$ & $1.00(0.32)$ & $0.10(0.76)$ & $0.01(0.92)$ & $0.46(0.50)$ \\
\hline 0.507 & 0.504 & 0.506 & 0.506 & 0.506 & 0.511 & & \\
\hline
\end{tabular}

Total savings is a snapshot of total financial assets held across all different types of instruments (the survey prompted for 12 different types, including "pocket").

Total amount borrowed is measured as a flow over the previous six months and elicited by prompting for loans from different types of lenders, and their originated loan amounts.

LHS variables in Cols (13) and (14) are elicited using 10-rung ladders, with higher rungs indicating higher wealth. 
Table 5: Treatment Effects on Income ('000 UGX)

\begin{tabular}{|c|c|c|c|c|c|c|c|c|}
\hline & $(1)$ & (2) & (3) & (4) & $(5)$ & (6) & (7) & $(8)$ \\
\hline LHS: & $\begin{array}{c}\text { Total Earnings } \\
\text { Last } 90 \text { Days }\end{array}$ & $\begin{array}{c}\text { Total Earnings: } \\
\text { Winsor Top } \\
5 \%\end{array}$ & $\begin{array}{c}\text { Total Earnings: } \\
\text { Winsor Top } \\
1 \%\end{array}$ & $\begin{array}{c}\text { Total Earnings: } \\
\text { Top } 1 \% \\
\text { Dropped }\end{array}$ & Farm Earnings & $\begin{array}{c}\text { Farm Earnings: } \\
\text { Winsor Top } \\
5 \%\end{array}$ & $\begin{array}{c}\text { Farm Earnings: } \\
\text { Winsor Top } \\
1 \%\end{array}$ & $\begin{array}{c}\text { Farm Earnings: } \\
\text { Top } 1 \% \\
\text { Dropped }\end{array}$ \\
\hline \multirow[t]{2}{*}{ Account Only } & 30.693 & $23.385^{*}$ & $31.404 * *$ & $36.985 * *$ & 22.510 & 7.266 & $14.244^{*}$ & 5.636 \\
\hline & $(33.472)$ & $(12.749)$ & $(15.911)$ & $(16.507)$ & $(14.221)$ & $(5.501)$ & $(8.092)$ & $(6.257)$ \\
\hline \multirow[t]{2}{*}{ Education Only } & 23.725 & $24.254^{*}$ & $29.608^{*}$ & $45.012 * * *$ & 10.435 & 4.875 & 11.264 & 4.117 \\
\hline & $(30.702)$ & $(13.112)$ & $(16.389)$ & $(16.230)$ & $(7.905)$ & $(4.817)$ & $(7.326)$ & $(5.671)$ \\
\hline \multirow[t]{2}{*}{ Account + Education } & 34.143 & $27.188^{* *}$ & $37.862 * *$ & $53.293 * * *$ & 5.586 & 4.232 & 10.156 & 6.498 \\
\hline & $(35.197)$ & $(12.784)$ & $(16.716)$ & $(17.998)$ & $(7.983)$ & $(5.165)$ & $(7.513)$ & $(6.206)$ \\
\hline Controls for Baseline Values & Yes & Yes & Yes & Yes & Yes & No & No & Yes \\
\hline $\mathrm{N}$ baseline miss val & 0.000 & 0.000 & 0.000 & 0.000 & 0.000 & 0.000 & 0.000 & 0.000 \\
\hline Observations & 2679 & 2679 & 2679 & 2652 & 2680 & 2680 & 2680 & 2652 \\
\hline Control Mean & 232.824 & 180.191 & 199.902 & 184.098 & 43.364 & 35.717 & 42.745 & 38.251 \\
\hline F-test (p-value): Acct $=$ Acct + Ed & $0.01(0.92)$ & $0.10(0.75)$ & $0.15(0.70)$ & $0.85(0.36)$ & $1.29(0.26)$ & $0.24(0.63)$ & $0.19(0.66)$ & $0.01(0.91)$ \\
\hline F-test (p-value): $\mathrm{Ed}=$ Acct $+\mathrm{Ed}$ & $0.12(0.73)$ & $0.06(0.81)$ & $0.22(0.64)$ & $0.22(0.64)$ & $0.22(0.64)$ & $0.01(0.91)$ & $0.02(0.90)$ & $0.12(0.73)$ \\
\hline F-test $(p$-value $):$ Acct $=E d$ & $0.06(0.80)$ & $0.01(0.94)$ & $0.01(0.91)$ & $0.25(0.62)$ & $0.61(0.43)$ & $0.16(0.69)$ & $0.10(0.75)$ & $0.05(0.83)$ \\
\hline Proportion of Obs Equal Zero & 0.119 & 0.119 & 0.119 & 0.121 & 0.544 & 0.544 & 0.544 & 0.549 \\
\hline
\end{tabular}

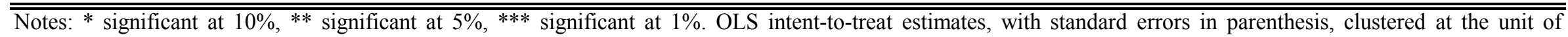

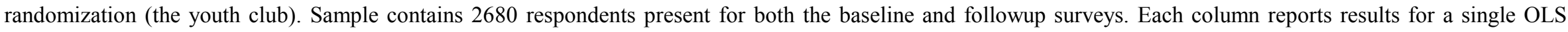

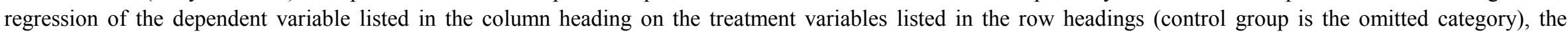

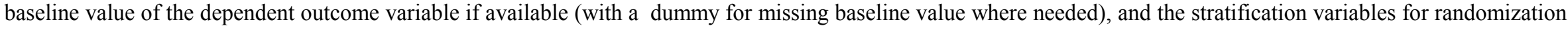

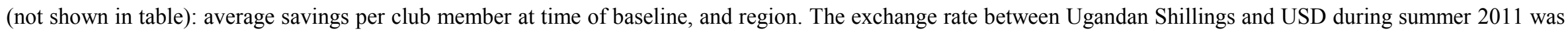
approximately 2500 to 1 .

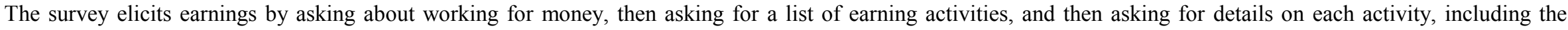
amount earned in the past 90 days. See the Data Appendix for details. 
Table 5 (cont): Treatment Effects on Income

\begin{tabular}{|c|c|c|c|c|c|c|c|c|c|}
\hline (9) & (10) & (11) & (12) & (13) & (14) & (15) & (16) & (17) & (18) \\
\hline $\begin{array}{l}\text { Informal } \\
\text { Earnings }\end{array}$ & $\begin{array}{c}\text { Informal } \\
\text { Earnings: } \\
\text { Winsor Top } \\
5 \%\end{array}$ & $\begin{array}{c}\text { Informal } \\
\text { Earnings: } \\
\text { Winsor Top } \\
1 \%\end{array}$ & $\begin{array}{c}\text { Informal } \\
\text { Earnings: Top } \\
\text { 1\% Dropped }\end{array}$ & $\begin{array}{l}\text { Busines } \\
\text { Ownership } \\
\text { Earnings }\end{array}$ & $\begin{array}{c}\text { Business } \\
\text { Ownership } \\
\text { Earnings: } \\
\text { Winsor Top } \\
5 \% \\
\end{array}$ & $\begin{array}{c}\text { Business } \\
\text { Ownership } \\
\text { Earnings: } \\
\text { Winsor Top } \\
1 \% \\
\end{array}$ & $\begin{array}{c}\text { Business } \\
\text { Ownership } \\
\text { Earnings: Top } \\
\text { 1\% Dropped }\end{array}$ & $\begin{array}{c}\text { Lent Any } \\
\text { Money Out } \\
\text { (last } 6 \text { months) }\end{array}$ & $\begin{array}{c}\text { Interest } \\
\text { Received from } \\
\text { a Borrower }\end{array}$ \\
\hline-10.368 & 7.488 & 4.629 & 7.846 & 8.628 & 4.333 & 8.752 & 8.439 & -0.004 & 1.032 \\
\hline (19.237) & $(6.707)$ & (10.649) & $(8.438)$ & $(16.426)$ & $(5.021)$ & (7.872) & (6.369) & $(0.024)$ & (1.233) \\
\hline 0.479 & $15.695^{* *}$ & 15.846 & $18.138 * *$ & -1.414 & -1.213 & 0.191 & 2.458 & -0.008 & -0.516 \\
\hline$(18.050)$ & $(7.314)$ & (11.666) & $(8.657)$ & (16.726) & $(4.742)$ & $(7.686)$ & $(6.025)$ & $(0.024)$ & $(0.870)$ \\
\hline 0.270 & $12.308 *$ & 13.715 & 14.159 & -0.359 & 3.816 & 8.355 & 6.886 & $0.045^{*}$ & 2.917 \\
\hline (18.066) & $(7.022)$ & $(11.750)$ & $(8.732)$ & $(14.880)$ & (4.993) & $(8.059)$ & $(6.279)$ & $(0.025)$ & $(3.024)$ \\
\hline Yes & No & No & Yes & Yes & No & No & Yes & Yes & No \\
\hline 0.000 & 0.000 & 0.000 & 0.000 & 0.000 & 0.000 & 0.000 & 0.000 & 5.000 & 0.000 \\
\hline 2680 & 2680 & 2680 & 2652 & 2680 & 2680 & 2680 & 2649 & 2680 & 2680 \\
\hline 81.120 & 46.367 & 60.631 & 49.892 & 51.522 & 28.749 & 38.336 & 29.242 & 0.709 & 2.069 \\
\hline $0.71(0.40)$ & $0.57(0.45)$ & $0.86(0.35)$ & $0.63(0.43)$ & $0.52(0.47)$ & $0.01(0.92)$ & $0.00(0.96)$ & $0.06(0.81)$ & $3.32(0.07)$ & $0.39(0.54)$ \\
\hline $0.00(0.99)$ & $0.24(0.63)$ & $0.04(0.85)$ & $0.23(0.63)$ & $0.01(0.93)$ & $1.19(0.28)$ & $1.12(0.29)$ & $0.49(0.49)$ & $4.13(0.04)$ & $1.25(0.26)$ \\
\hline $0.73(0.39)$ & $1.54(0.22)$ & $1.36(0.24)$ & $1.77(0.18)$ & $0.47(0.49)$ & $1.44(0.23)$ & $1.31(0.25)$ & $0.88(0.35)$ & $0.02(0.88)$ & $1.83(0.18)$ \\
\hline 0.566 & 0.566 & 0.566 & 0.572 & 0.774 & 0.774 & 0.774 & 0.783 & 0.284 & 0.890 \\
\hline
\end{tabular}


Table 6: Treatment Effects on Activities

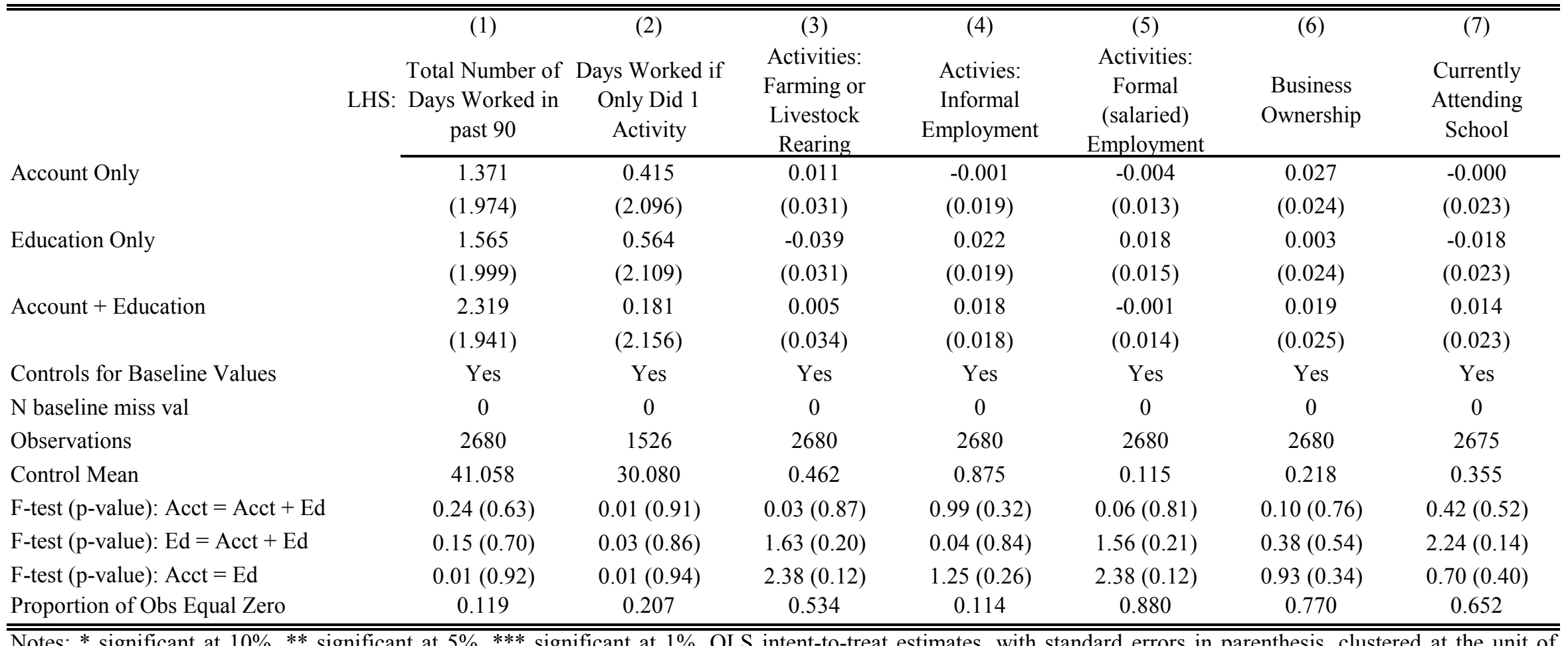

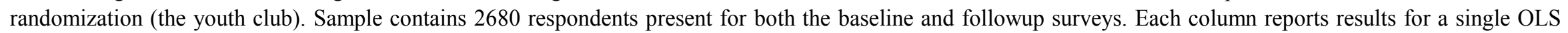

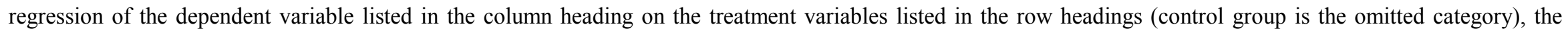

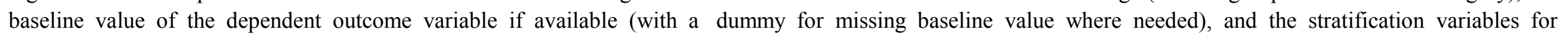
randomization (not shown in table): average savings per club member at time of baseline, and region.

\section{Outcomes:}

(1) We sum the number of days worked for each activity, and topcode at 90 because some respondents worked partial days on several activities.

(3)-(6) take the value of 1 if respondent reports income from that activity during the past 90 days, and 0 otherwise.

(4): Informal activies include Build/Construction, Quarrying, Salon, Boda/Taxi driving, Work in other HH, Work in own HH, Small Scale Vocation, Non-Salary (Wage) Church, Other Wage employ, Other, Brewing Alcohol, Fetching Water, Collecting Firewood, Computer Related, Fishing, Music, Nursing, Drama, Sports, Sewing, Rent 
Table 7: Treatment Effects on Expenditures ('000 UGX)

\begin{tabular}{|c|c|c|c|c|c|c|c|c|c|}
\hline LHS: & $\begin{array}{l}\text { Money Spent } \\
\text { in Last } 7 \text { days }\end{array}$ & $\begin{array}{c}\text { Money Spent } \\
\text { on Snacks } \\
\text { Last } 7 \text { days }\end{array}$ & $\begin{array}{l}\quad 1=\text { Owns } \\
\text { mobile phone }\end{array}$ & $\begin{array}{c}\text { \# of Meals w/ } \\
\text { Meat last } 7 \\
\text { days }\end{array}$ & $\begin{array}{l}\text { Airtime Used } \\
\text { last } 7 \text { days }\end{array}$ & $\begin{array}{l}\text { \# of People } \\
\text { you Support } \\
\text { Financially }\end{array}$ & $\begin{array}{c}(7) \\
\text { Own Money } \\
\text { Spent on } \\
\text { Health } \\
\text { Related Exps. } \\
\text { last } 6 \text { mths } \\
\end{array}$ & $\begin{array}{c}(8) \\
\text { Own Money } \\
\text { Spent on } \\
\text { School Fees } \\
\text { last } 6 \text { mths }\end{array}$ & $\begin{array}{c}\text { (9) } \\
\text { Own Money } \\
\text { Spent on } \\
\text { Business } \\
\text { Investment } \\
\text { last } 6 \text { mths } \\
\end{array}$ \\
\hline Account Only & $\begin{array}{l}-0.717 \\
(5.259)\end{array}$ & $\begin{array}{l}-0.309 \\
(0.882)\end{array}$ & $\begin{array}{l}-0.031 \\
(0.025)\end{array}$ & $\begin{array}{c}0.172 \\
(0.131)\end{array}$ & $\begin{array}{c}0.067 \\
(0.270)\end{array}$ & $\begin{array}{c}0.210 \\
(0.164)\end{array}$ & $\begin{array}{c}43.380 \\
(50.474)\end{array}$ & $\begin{array}{c}12.814 \\
(16.273)\end{array}$ & $\begin{array}{c}-8.111 \\
(54.153)\end{array}$ \\
\hline Education Only & $\begin{array}{c}0.086 \\
(5.398)\end{array}$ & $\begin{array}{l}-0.561 \\
(0.786)\end{array}$ & $\begin{array}{c}0.011 \\
(0.026)\end{array}$ & $\begin{array}{l}0.193 * \\
(0.114)\end{array}$ & $\begin{array}{c}0.091 \\
(0.246)\end{array}$ & $\begin{array}{c}0.268 \\
(0.179)\end{array}$ & $\begin{array}{c}-0.986 \\
(13.460)\end{array}$ & $\begin{array}{c}11.773 \\
(14.739)\end{array}$ & $\begin{array}{l}-13.782 \\
(51.090)\end{array}$ \\
\hline Account + Education & $\begin{array}{l}-0.249 \\
(4.886)\end{array}$ & $\begin{array}{l}-0.012 \\
(0.899)\end{array}$ & $\begin{array}{c}0.001 \\
(0.026)\end{array}$ & $\begin{array}{l}0.231 * \\
(0.123)\end{array}$ & $\begin{array}{c}0.226 \\
(0.279)\end{array}$ & $\begin{array}{c}0.089 \\
(0.167)\end{array}$ & $\begin{array}{c}-9.766 \\
(13.483)\end{array}$ & $\begin{array}{c}10.106 \\
(14.119)\end{array}$ & $\begin{array}{l}-24.914 \\
(49.444)\end{array}$ \\
\hline Controls for Baseline Values & Yes & Yes & Yes & Yes & Yes & Yes & Yes & Yes & Yes \\
\hline $\mathrm{N}$ baseline miss val & 0.000 & 179.000 & 0.000 & 0.000 & 3.000 & 5.000 & 2.000 & 0.000 & 0.000 \\
\hline Observations & 2678 & 2627 & 2679 & 2679 & 2679 & 2680 & 2679 & 2679 & 2673 \\
\hline Control Mean & 31.768 & 3.517 & 0.662 & 1.942 & 2.090 & 2.333 & 62.482 & 24.322 & 141.295 \\
\hline F-test (p-value): Acct $=$ Acct + Ed & $0.02(0.90)$ & $0.27(0.60)$ & $2.11(0.15)$ & $0.20(0.65)$ & $0.36(0.55)$ & $0.48(0.49)$ & $1.15(0.28)$ & $0.03(0.87)$ & $0.26(0.61)$ \\
\hline F-test (p-value): $E d=$ Acct $+E d$ & $0.01(0.93)$ & $1.21(0.27)$ & $0.17(0.68)$ & $0.11(0.74)$ & $0.33(0.56)$ & $0.90(0.34)$ & $1.25(0.26)$ & $0.01(0.92)$ & $0.14(0.71)$ \\
\hline F-test (p-value): Acct $=E d$ & $0.03(0.85)$ & $0.34(0.56)$ & $3.49(0.06)$ & $0.03(0.86)$ & $0.01(0.91)$ & $0.10(0.76)$ & $0.81(0.37)$ & $0.00(0.95)$ & $0.02(0.88)$ \\
\hline Proportion of Obs Equal Zero & 0.020 & 0.288 & 0.341 & 0.236 & 0.240 & 0.380 & 0.072 & 0.974 & 0.518 \\
\hline
\end{tabular}

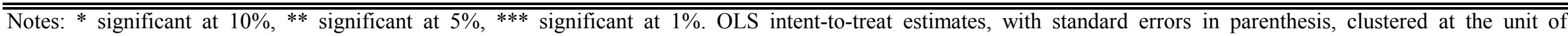

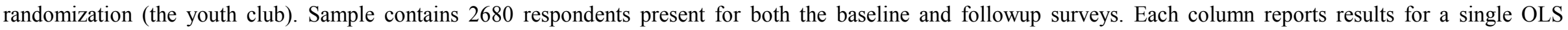

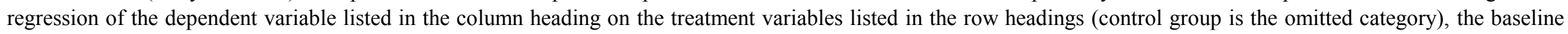

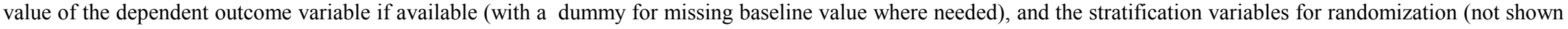

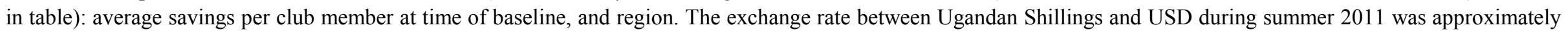
2500 to 1 .

Outcomes:

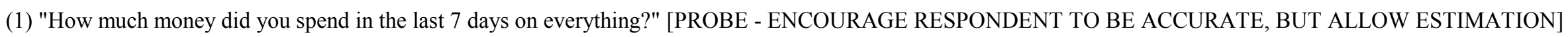

(4) "Meat" includes chicken.

(5) We estimate airtime value by eliciting minutes used, and multiplying that by the market price.

(6) "How many people do you give financial support to regularly? This could include children or adults, and people who live with you or people outside of your home."

(9) "How much money total did you spend on investments in business in order to try to make profits in the past 6 months? It is okay to estimate." 